\title{
Is Anyone Out There Listening?
}

\author{
Marilyn Stokstad \\ Judith Harris Murphy Distinguished Professor of Art History \\ University of Kansas
}

"Once more into the breach, dear friends, or close the gap with the bodies of"... a comatose public. Is Anyone Out There Listening?

As scholars we know how to share information rapidly with the people who need to know. As I was typing some notes for this talk, Prof. Harry Titus from Wake Forrest stopped by on his way to Colorado. Just back from a symposium in Burgundy, he passed along the latest news on the $8^{\text {th }}$ and $9^{\text {th }}$ century crypt under the Cathedral of Auxerre-and the address of his web page where I can see the new photos of the work-a nice mix of traditional information sharing - that is to say, personally and verbally and electronically. (In return, I directed him to Lucas, Kansas and the Garden of Eden, something every medievalist should see).

The important question is not how we enhance scholarly communication among ourselves but how we communicate with a wider audience. First and foremost we teach. Teaching remains the finest (noblest?) form of scholarly communication. Of course when we teach, we do more than transmit information. We also teach how to use information, how to evaluate ideas, and (we hope) how to create more "knowledge."

Good teaching does not have to consist of one to one communication. The image of two people-student and teacher-sitting on a log, may have been unduly praised. Today one to one communication may come through a machine-without human contact. With present low funding for education, we must get our material across to massed students. That's OK. Large lectures-or massed computer screens-can be electrifying. An electronic classroom may be effective for high school students who come to us lacking (shall we say) the contemplative mode, or for highly motivated people who need factual information-and know they need it. But to inspire people we need to establish personal relationships (today, I still need my e-mail or my Art History 150-151 web site).

For sheer rapid accurate dissemination of information, nothing beats the combination of images and words. You will recall the memorable image of the Frankfurter queen of 1952, for example. The arts (in this case photography) have always been in the forefront of transmitting vital 
information. The earliest art, painting in caves, still communicates its message: man down, bison disemboweled, and hairy rhino running off, warning, instruction, shaman's trance?) In ancient Rome there is a splendid piece of imperial propaganda for Augustus (an image saying through the ages I will convince you or bury you). Here is a man in his 60's, his body armor turning him into a super warrior, his bare feet indicating his status as a demigod. Demi Gods still stare out at us from magazine covers-did this Hercules read Charles Atlas ads? Was he a 98 pound weakling with sand in his face? Sex sells-and so do pictures. Did you rush out and buy Taboo perfume after seeing this ad in Vogue? And today we have learned that pictures still communicate faster and more effectively than words. Or at least that's what Calvin Kline people decided.

Lots of people are looking.

Is anyone out there also reading?

When Henry $V$ led the English against the French at Agincourt, the world as he knew it-the world of information through pictures and oral history and poetry - was crumbling before the force of a new technology more powerful than his English longbowmen. In the 15th century, "The Age of Mechanical Reproduction" dawned. Soon the printing presses would be making the labors of countless scribes as obsolete as the French knights in heavy armor. Henry's stirring words-"once more into the breach," or whatever he actually said-would today be a press release, leaving later day Willie Shakespeares with less scope for their imaginations.

Scholars throughout the western world would use the new technology to create multiple, nearly identical images and to disseminate their theories and discoveries (e.g. The sex life of the mandrake plant). When images as well as words could be reproduced, everyone could argue from the same page. For herbalists and alchemists a rose could no longer be a symbol of a flower but must resemble a rose seen in nature. Herbalists would become botanists and alchemists became chemists. They were people who changed things-into other things, grapes into alcohol for example (e. g. the distillery, and samplers).

How patrons in the $15^{\text {th }}$ and $16^{\text {th }}$ centuries must have despaired at the cost of setting up an alchemist's lab when every Tommaso, Ricardus, and Henricus could see-and demand-the latest equipment! See what Rudolph II is giving his team in Prague! Have you heard about the breakthroughs the Prince Henry group is making in Portugal? Their breathtaking study of Atlantic tradewinds. And what about that mad Genoese sailing for Isabella? He claims he just discovered a new world-where people 
wear feathers and eat people. One amazing thing after another and all spread with the speed of the new printing presses.

But wait. As we know, new technology can be double edged. Remember who first profited from the new technology-advertisers, gamblers, and propagandists. The earliest prints advertised saints' shrines and relics and became souvenirs of pilgrimage travel (prints made by and highly profitable for the churches and monasteries holding miracle working relics). Printers also made playing cards (known as paper dice and originally hand painted-imagine the possibilities of fraud). And, of course, printing spread vicious political propaganda!

The real trouble makers did not originate in Silicon Valley but in the Rhein-Main. Gutenberg in Mainz dramatized the full force of the information explosion with another break-through-moveable type. More and more people could afford books, and they read them. Words and images-the power of the media was born in the Protestant Reformation-Luther vs. the Pope.

Now 500 years later, the computer age has dawned as brightly as the age of printed books - I mean "hard copy"-or do I mean "hand held reading devices"? And human beings, the stubborn survivors, faced the same challenges all over again. On the plus side - speed and accuracy-if handled well. On the minus side-plagiarism, theft, lies and slander. Information or disinformation. How to share? With whom to share? Can we protect information and ideas? Should we? How do we apportion credit? Rewards? In the visual arts, for example, "appropriation" is a major toolcreative reuse of other's work makes intellectual property issues very controversial.

Visual images are long lasting (many of you seem to remember the Charles Atlas ads). The most effective way to get out a message remains visual. The magazine or newsletter arrives in ones home or office. Then action is required to get rid of it, not to keep it. And even in the act of discarding, the eye may stop the hand. Herein lies the communicators' challenge-to capture the readers' attention in that glance. Once caught, the modern reader demands a succinct, pointed text. Sometimes even "bullets" not paragraphs. The point is that we learn rapidly from images, even the Frankfurter Queen.

The mission for all of us in universities is clear-we must communicate with everyone because we-and our friends-cannot function without wide public support. But, as our speech and writing becomes ever more technical, and we depend on private in-group-speak for scholarly communication, the 
public can no longer respond to us. For the researcher it is important to maintain a high level of scholarship, even while simplifying and popularizing.

Roger Martin (KU's excellent science writer) distributes the blame for poor communications equally among four groups:

$>$ the public (who present us with a challenging combination of curiosity and ignorance);

$>$ the media (who reject an educational role and define news in their often sensational own way);

$>$ the scholars (who are, as Martin says, "less than silver tongued," and-as I know too well-fear the stigma of being known as popularizers);

$>$ and his own colleagues, the official public relations people (who under pressure may turn out little other than snooze-o press releases).

I defer to Roger's experience and judgment, but I think scholars and public actually want the same thing. Researchers are relentlessly curious enthusiasts who may hit upon their best ideas in moments of relaxation or sheer zaniness (like Bruce Naumann turning himself into a fountain). Most folks outside academe are also eager and curious but they, too, want entertainment with their information. In other words, at heart, both producers and consumers of our research "product" agree; they hope for exciting new stuff arrived at and presented with a bit of pizzazz. Coming between the two are serious, stuffy officials and media types who spoil the fun-with certain exceptions of course.

What we want and need are translators-like the University of Missouri's "Mizzou Magic."

The job of scholarly communication falls to all of you-senior members of the academic community, especially those of you who have left your ivy-ed halls for the cubicles of administration-luxury cubicles perhaps but cubicles all the same. You must defend the professors who are tongue-tied by their own jargon, belittled by legislators for their esoteric interests, and swamped by demands of the university bureaucracy. You must create and sustain a public interest in their expensive and time consuming work. To do this you need bright creative people to help you, not Dilberts with PowerPoint.

Remember-artists and humanists have long been the experts-using sounds and images as the primary means of information transmission, carried by individuals but transmitted to the tribe. Epic poetry conveyed belief systems and so did theater, dance, ritual, pageant, liturgy. Public art, painting and sculpture formed a permanent record of ideals and beliefs-knowledge that meant survival. 
Artists like Nam June Paik remind us with his "Computer Parents," that when communication is no longer limited by human voice or eye or ear, we have become isolated as never before. The meeting of minds, researcher to researcher, becomes ever easier even as human contact shuts down. Both as originators and recipients of information, we often sit alone in our boxes communicating by machine. But boxed communication will not do for everyone. Vital communication with the public goes far beyond today's theme of university alliances. 